logical method of research. Although it is widely appreciated that in the archæological studies of the last generation nothing has contributed more fruit. fully to understanding of the culture of the stone age than the interpretation of the palæolithic cave paintings of southern France and Spain by reference to the magical and religious beliefs of modern 'savages', nevertheless many archæologists hesitate to press such analogies. They point to the unquestionable fact that the culture of the modern 'primitive' has not been static over a long period, but has itself been the subject of an evolutionary process, even though they may admit with Dr. Balfour that change has been slow, when no extraneous element has been implicated. Yet instances of the prolonged persistence of unchanged tradition do undoubtedly occur. An interesting illustration bearing on the argument is afforded by Mr. S. Casson's study in Antiquity of December last of survivals among ceramic types now eurrent in Cyprus and the islands of the Egean, belonging to a tradition which extends back not only to medieval times, but even in some instances to the bronze age. He points out how the methods of manufacture, marketing and distribution between the islands and to the mainland still followed at the present day may serve, with their Homeric flavour, to throw light on the obscure field of the early industrial and commercial organization of the eastern Mediterranean, about which so little is known in detail.

\section{Research in Mental Disease at Birmingham}

ON February 9, a memorial plaque to the memory of the late Sir Frederick Mott was unveiled by Lady Mott in the Medical School of the University of Birmingham at Edgbaston. The plaque, which is the work of Miss Phyllis Mott, the daughter of Sir Frederick, was the gift of Dr. H. A. Pullar Strecker. Sir Gilbert Barling, in an introductory address, said that the Joint Board for Research in Mental Disease has now found its home in the new Medical School of the University, where it has excellent laboratory accommodation. The laboratory was originally opened at Hollymoor in 1923 by the Minister of Health (the present Prime Minister) with Sir Frederick Mott as honorary director of the Joint Board of Research, and Dr. F. A. Pickworth as chief research officer. It was hoped that the mental hospitals in the surrounding counties would join in the research, and this hope is now fulfilled by Staffordshire, Leicestershire, Worcestershire and Shropshire. Sir Gilbert acknowledged the generous help of Sir Charles Hyde both in 1923 and at the present time. Funds are now available for the appointment of another full-time research officer of high standing to study the influence of viruses and hormones as causes of mental disease, and a surplus is to be used to provide the stipend of a research scholar for three or four years.

\section{Roman Road near East Grinstead}

A Roman road, which is described as "one of the most perfectly preserved of its type in Britain", has been discovered in a field at Holtye near East Grinstead (The Times, February 13). It is part of the old Roman highway which ran from London to Lewes and here crosses a field. The land on which it is situated has been purchased by Mr. I. D. Margary, a Sussex archæologist, for the purpose of investigation and later preservation. At present a stretch of the road, about 85 yards long and varying in width from 15 to $18 \mathrm{ft}$., has been uncovered. Wheel marks are plainly visible; but the iron-slag surface has rusted together so solidly as to form a mass almost as hard as concrete, and consequently in an excellent state of preservation. In certain places it has been necessary for the workmen to remove soil to a depth of three feet to reach the surface of the road. The remains of vegetation several inches in depth indicate that at one time a forest grew over the road.

\section{Research in Electrical Industries}

LoRd Stamp, the new president of the British Electrical and Allied Industries Research Association, when addressing members at a luncheon which followed the annual meeting in London on February 10 , laid stress on the value of research in industry. He pointed out that the electrical industry takes a leading place in research because it has no real industrial or commercial history apart from the history of research and invention. Most industries grow out of, and often cling to, primitive operations on raw materials to supply age-old needs. Scientific research, if added to them, complicates them; and many think that these additions are a doubtful advantage if they cannot be confined to benefit those who promote them. They think that it makes competition more keen in various branches of the industry and often, as well, creates unnecessarily rapid obsolescence in plants still working. The whole genesis of the electrical industry has been different; it was born out of research and is meeting the created needs of an advanced civilization. Continuous research is its natural sustenance. The work of this Association is an excellent example of co-operation between manufacturers and users; it pools their ideas, thus ensuring that both sides get full benefit from them.

\section{Thermal Power Plants for Emergency Service}

A MAJOR interruption of the electric supply in $\mathbf{a}$ city of any importance is nowadays attended with disastrous consequences. The provision of some reserve source of power, capable of supplying the vital services at least, is therefore imperative when such failures can occur. The main causes of failures are breakdowns of transmission lines, strikes or enemy bombardment. A paper read by Mr. Hvistendahl on November 10 to the Institution of Electrical Engineers distinguishes between the different classes of service to be furnished by stand-by plants. Descriptions are given of automatic and semiautomatic stand-by plants used in towns in Norway and Sweden. Although unthinkable a few years ago, the bomb-proof emergency service station is now a grim reality. Sandbags provide some protection against fragments of stray shells or bombs, but they are little use against repeated attacks from the air, 
and a large steam-power station is an easily located target. This has led to the construction in several countries of the Continent of bomb-proof stand-by power plants for the essential services in towns or districts or for supplying the power requirements of munition factories. These plants are either of the surface or of the underground type. The plan of a station for an output of $10,000 \mathrm{kw}$. is shown located in a tunnel cut into the face of a cliff. The turbo-set, boiler and tanks containing sufficient fuel for 7-10 days' service, and the auxiliary starting set, are accommodated in a gallery about $150 \mathrm{ft}$. long and of about the section of a normal double-track railway tunnel. When ground conditions are not favourable to such a disposition, or the danger of flooding exists, a station of the surface type is adopted, with roof and walls of reinforced concrete about $4 \mathrm{ft}$. thick, having the appearance of a block of dwelling houses or made inconspicuous in some other way.

\section{A Naturalists' Directory}

WE have recently received a copy of the thirty-first edition of the "Naturalists' Diary" (Salem, Mass., U.S.A. : The Cassino Press. 3 dollars). It contains the names, addresses and special subjects of professional and amateur naturalists of North and South America, etc. This list will prove very useful to naturalists in the United States, since for that country it seems comprehensive; but in other countries, such as Great Britain, its usefulness is impaired by the sparsity of entries. For example, for the State of New York alone there are about four hundred and fifty entries, while for the whole of Great Britain there are only eleven; for France, six and for Germany, six. The list should prove useful, however, to naturalists outside the United States who wish to get in touch with their American contemporaries. Appended to this directory is a short list of scientific periodicals. While in the compilation of such a list it is naturally essential to be selective, it is difficult to understand what policy was adopted by the compilers, since it is rather inconsistent. Most of the periodicals are American ; but even here it is difficult to see why the Journal of Applied Physics should be included in a list for naturalists, and the Botanical Gazette omitted. Again, among the British journals is included the Journal of the Chemical Society, but not the Aquarist and Pondkeeper or Discovery. Of foreign journals, only Scientia and Helvetica Physica Acta are mentioned, whereas journals of international appeal to naturalists, such as Chronica Botanica, are omitted. The price for a paper-covered book of about 230 pages is high.

\section{Periodicals for Medical and Scientific Libraries}

THE selection of periodicals for medical and scientific libraries is discussed by C. C. Barnard, librarian of the London School of Hygiene and Tropical Medicine, in a paper in the Library Association Record of November, 1938. Mr. Barnard gives a comparison of results obtained by Gross and Gross' method of arranging periodicals in order of importance as indicated by the frequency of bibliographical reference to them, taking the Journal of the American Chemical Society for 1927 instead of the 1926 volume as used by Gross and Gross. Although agreement is satisfactory at the top of the scale, there are considerable variations lower down, and Mr. Barnard points out that, besides the inherent limitations of the method, which does not take account of frequency of publication of the periodicals or of the length of their articles, comparison on the basis of one year's references is too narrow to be trustworthy. Results obtained at the London School of Hygiene and Tropical Medicine for a large number of medical periodicals by marking each volume or part on the table before return to the shelves are tabulated and discussed, particularly as a check upon the personal selection of experts. Mr. Barnard directs attention to the infrequent reference to the earlier volumes of even such periodicals as Annales de l'Institut Pasteur and Zeitschrift für Hygiene, and suggests that the compilation of similar records by all libraries co-operating in the inter-library loans system might permit recommendations on the basis of a comprehensive survey which would effect appreciable savings in postage and also in time and labour by the redistribution of certain periodicals among the participants.

\section{ASLIB Conference Report}

THE report of proceedings of the fifteenth Conference of the Association of Special Libraries and Information Bureaux (price 5s.), which has just been issued, contains the text of papers presented at the Conference together with summaries of some of those presented at the joint session with the International Federation for Documentation on the organization of information services. An additional paper from Mr. G. Lightfoot, secretary, Council for Scientific and Industrial Research, Commonwealth of Australia, on the establishment of an information service by that Council is also included, as well as summaries of certain papers contributed to the joint session on 'tools' for library co-operation and reports received from the National Central Library and the British Society for International Bibliography.

\section{Air Raid Precautions in Hospitals}

A воOKLET containing advice on the structural and other precautions that can be taken against air raid risks in hospitals has been issued jointly by the Ministry of Health and the Department of Health for Scotland to all local authorities controlling hospitals and also to voluntary hospitals (London : H.M. Stationery Office. 3d. net). Hospital authorities are urged to proceed at once with the precautions recommended, the extent to which they do so depending in some degree on the likelihood of air attack in the area. Measures are described for the adaptation of existing buildings, as well as structural features suggested for new buildings. The Government is prepared to contribute to the cost of these measures under certain conditions. 